\title{
CONF-970476--2
}

\section{FRACTURE ASSESSMENT OF DUCTILE CRACK GROWTH IN WELD MATERIAL FROM A FULL-THICKNESS CLAD RPV SHELL SEGMENT}

\author{
J. A. KEENEY \\ Oak Ridge National Laboratory \\ P. O. Box 2009, Oak Ridge, TN, USA, 37831-8056 \\ MASTER \\ RECEIVED \\ NOV 191996 \\ OSTI

\begin{abstract}
MGTE

Recent studies indicate that the onset of stable ductile tearing leads to crack-tip fields ahead of the growing crack and crack-tip profiles that differ from those of a stationary crack. Stable ductile tearing exposes additional volumes of material to elevated stresses as the crack advances, which alters the sampling of potential cleavage initiation sites on the microstructural level. Also, measured cleavage fracture toughness values for these specimens will be influenced by changes in crack-tip constraint conditions that occur with prior stable crack growth. Fracture analysis techniques for inclusion of ductile crack growth in finite-element analyses were evaluated through applications to a full-thickness clad beam specimen containing a shallow crack in material for which metallurgical conditions are prototypic of those found in reactor pressure vessels (RPVs) at beginning of life. The beam specimen, which experienced a significant amount of precleavage stable ductile tearing, was fabricated from a section of an RPV wall (removed from a canceled nuclear plant) that includes weld, plate, and clad material. Effects of precleavage tearing on estimates of fracture toughness were investigated using continuum damage models.
\end{abstract}

\section{KEYWORDS}

Reactor pressure vessel, full-thickness clad beam, shallow-crack, compact tension specimen, precleavage tearing, continuum damage models

\section{INTRODUCTION}

Evaluations of reactor pressure vessel (RPV) integrity under pressurized-thermal shock (PTS) loading are based on the Marshall flaw distribution (Marshall, 1982), U.S. Nuclear Regulatory Commission (NRC) Guide 1.154 (1987), and data from deep-crack fracture toughness specimens. The Marshall flaw distribution predicts more small (shallow) than large (deep) flaws, while NRC Regulatory Guide 1.154 requires that all flaws be considered as surface flaws. Probabilistic fracture-mechanics (PFM) analyses of RPVs indicate that a high percentage of the cracks that initiate in cleavage, initiate from shallow flaws (Cheverton, 1985). Because the postulated existence of shallow flaws has a dominant influence on the results of PFM analyses and, ultimately, the conditional probability of vessel failure in a PTS evaluation, the shallow surface crack is of major importance in RPV structural integrity assessments.

Fracture analysis techniques were used to investigate results from a Heavy-Section Steel Technology (HSST) testing program designed to quantify fracture toughness for shallow cracks in weld material for which metallurgical conditions are prototypic of those found in RPVs at 


\section{DISCLAJMLRR}

Portions of this document:may be illegible in electronic:image products. Images;are: produced from the best available original: document: 


\section{DISCLAIMER}

This report was prepared as an account of work sponsored by an agency of the United States Government. Neither the United States Government nor any agency thereof, nor any of their employees, makes any warranty, express or implied, or assumes any legal liability or responsibility for the accuracy, completeness, or usefulness of any information, apparatus, product, or process disclosed, or represents that its use would not infringe privately owned rights. Reference herein to any specific commercial product, process, or service by trade name, trademark, manufacturer, or otherwise does not necessarily constitute or imply its endorsement, recommendation, or favoring by the United States Government or any agency thereof. The views and opinions of authors expressed herein do not necessarily state or reflect those of the United States Government or any agency thereof. 
beginning of life. In the first phase of the investigation, five full-thickness clad beam specimens taken from the RPV of a canceled nuclear plant were fabricated at Oak Ridge National Laboratory and tested at the National Institute for Standards and Technology, Gaithersburg, Maryland. These tests were performed to determine the influence of material properties gradients, weld inhomogeneities, weld defects and the cladding process on the fracture toughness of material containing shallow cracks. Through-clad shallow cracks in these beams were machined in the weld material joining together two plate material shell segments.

In the first four tests (CB-1.1 - CB-1.4), the cracks initiated in cleavage thus allowing the use of static analysis techniques. The fifth specimen (CB-1.5) experienced $\sim 2.6 \mathrm{~mm}$ of stable ductile tearing prior to initiation of cleavage fracture. Recent studies (Ruggieri and Dodds, 1995) indicate that the onset of stable ductile tearing leads to crack-tip fields ahead of the growing crack and crack-tip profiles that differ from those of a stationary crack. Stable ductile tearing exposes additional volumes of material to elevated stresses as the crack advances, which alters the sampling of potential cleavage initiation sites on the microstructural level. Also, measured cleavage fracture toughness values for these specimens will be influenced by changes in crack-tip constraint conditions that occur with prior stable crack growth. The analysis of CB-1.5 utilized the Gurson-Tvergaard (G-T) dilatant plasticity model (Gurson, 1977) for void growth and element extinction capability for modeling crack growth.

\section{FULL-THICKNESS CLAD BEAM TESTING PROGRAM}

The full-thickness clad beam specimens were fabricated from an RPV shell segment that was available from a canceled pressurized-water reactor plant (the plant was canceled during construction, and the vessel was never in service). The RPV material is A 533 B steel with a stainless steel clad overlay on the inner surface. The shell segment contains three submerged-arc welds (two circumferential welds and one longitudinal weld). The plate material, clad overlay, and weldment are completely prototypic of a production-quality RPV.

Because the first series of five specimens was intended to investigate the fracture behavior of the longitudinal weld material, the test beams were cut in the circumferential direction of the shell. A sketch of the specimen geometry is shown in Fig. 1. The specimen was designed to be tested in three-point bending. The flaw was machined in the beam using the wire electro-discharge machining process and extended from the shell inner surface, that is, the clad surface, to predetermined depths into the beam. The final dimensions for each beam are shown in Table 1.

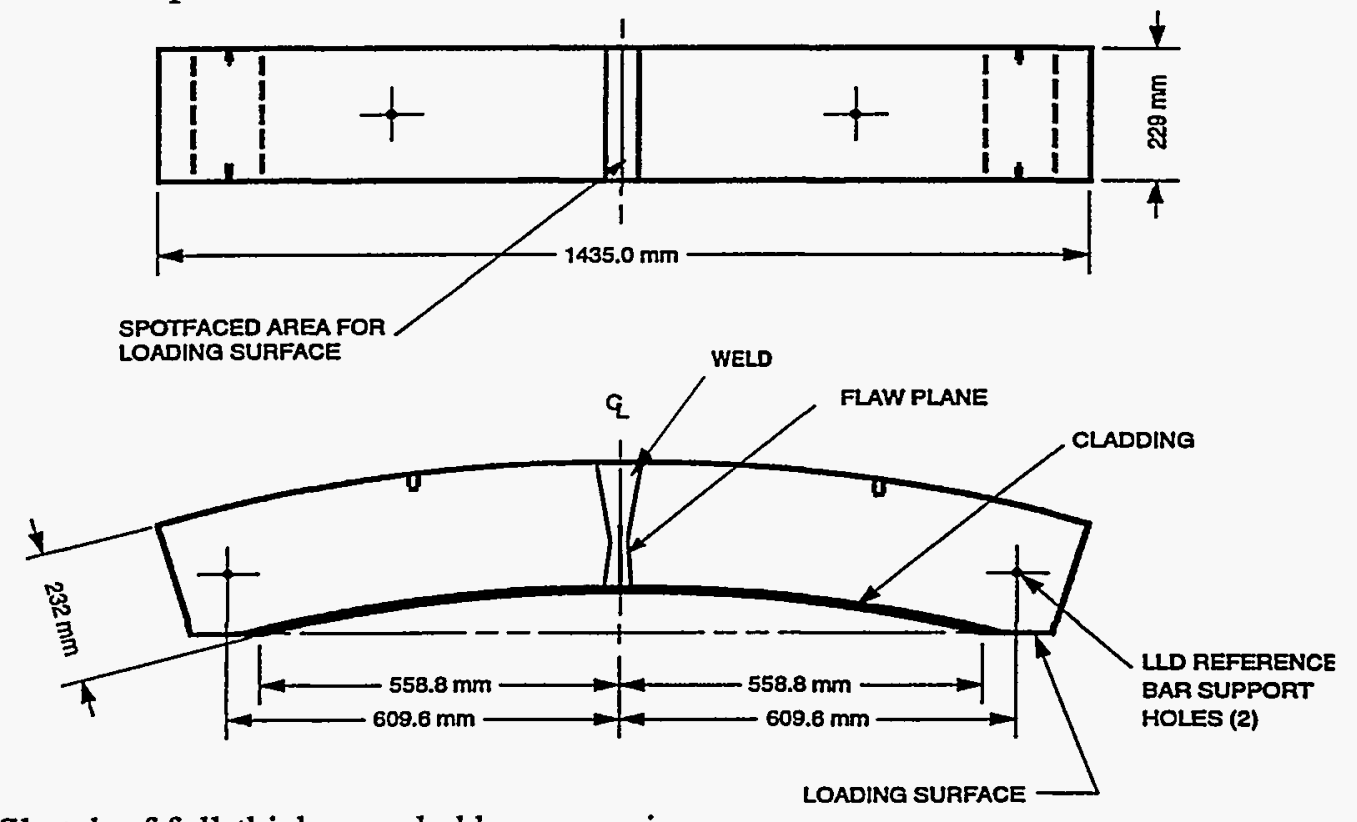

Fig. 1 Sketch of full-thickness clad beam specimen. 
Table 1 Parameters defining specimen geometry of full-thickness clad beam specimens

\begin{tabular}{|c|c|c|c|c|c|}
\hline & $\mathrm{CB}-1.1^{\mathrm{a}}$ & CB-1.2 & CB-1.3 & CB-1.4 & CB-1.5 \\
\hline Load span, S (mm) & 1219.2 & 1219.2 & $\overline{1219.2}$ & 1219.2 & 1219.2 \\
\hline Thickness ${ }^{b}, \mathrm{~B}(\mathrm{~mm})$ & 230.2 & 230.2 & 229.6 & 229.1 & 231.6 \\
\hline Width, W (mm) & 225.7 & 224.3 & 224.3 & 228.9 & 225.0 \\
\hline Crack depth' $^{c}, a(\mathrm{~mm})$ & 117.5 & 10.8 & 23.7 & 22.6 & 12.1 \\
\hline Ratio, a/W & 0.50 & 0.05 & 0.10 & 0.10 & 0.05 \\
\hline
\end{tabular}

${ }^{\mathrm{a}}$ Development beam, ${ }^{6}$ Thickness includes $\sim 5 \mathrm{~mm}$ of clad overlay, ${ }^{\mathrm{C}}$ Final depth after fatigue precracking.

The J-integral resistance (J-R) curves were determined for the longitudinal weld using 1T compact tension (CT) specimens sidegrooved $10 \%$ of their thickness on each side. The specimens were fatigue precracked at room temperature and tested at $50^{\circ} \mathrm{C}$ (lowest temperature where tearing was achieved in test) to obtain full $\mathrm{J}-\mathrm{R}$ curves (the target was $2 \mathrm{~mm}$ of crack extension). The J-R curves are shown in Fig. 2, and the $\mathrm{J}_{\mathrm{Q}}$ values and tearing moduli $(\mathrm{T})$ are given in Table 2. Impact and tensile data were used to develop a consistent set of material properties needed for evaluation of the clad beam test data. These properties are listed in Table 3.

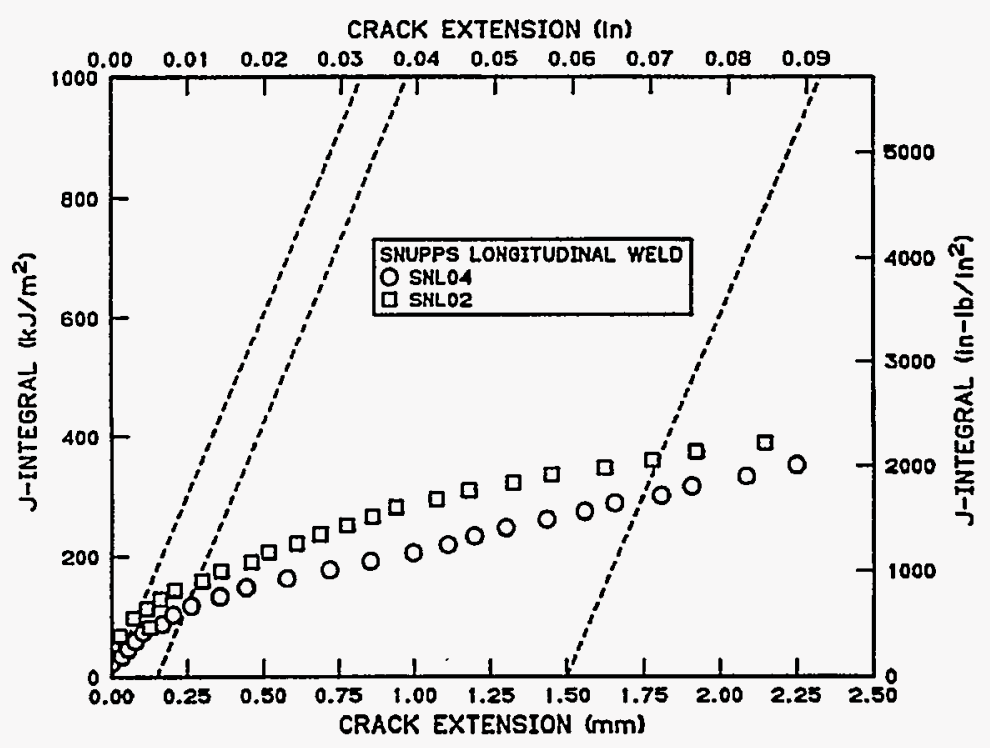

Fig. $2 \mathrm{~J}-\mathrm{R}$ curves for $1 \mathrm{~T}-\mathrm{CT}$ specimens tested at $50^{\circ} \mathrm{C}$.

Table 2 Fracture toughness test results

\begin{tabular}{ccccc}
\hline Material & Specimen & $\begin{array}{c}\text { Test } \\
\text { Temperature } \\
\left({ }^{\circ} \mathrm{C}\right)\end{array}$ & $\begin{array}{c}\text { Fracture } \\
\text { Toughness, } \\
\left(\mathrm{kJ} / \mathrm{m}^{2}\right)\end{array}$ & $\begin{array}{c}\text { Tearing } \\
\text { Modulus } \\
(\mathrm{T})\end{array}$ \\
\hline Weld & SNL04 & 50 & 116 & 67 \\
& SNL02 & 50 & 171 & 77 \\
\hline
\end{tabular}

Table 3 Material properties at test temperature of $-25^{\circ} \mathrm{C}$

\begin{tabular}{llll}
\hline & $\begin{array}{l}\text { Base } \\
\text { metal }\end{array}$ & $\begin{array}{l}\text { Weld } \\
\text { metal }\end{array}$ & Cladding \\
\hline Modulus of elasticity $(\mathrm{E}), \mathrm{MPa}$ & 200,000 & 212,000 & 152,000 \\
Poisson's ratio $(v)$ & 0.3 & 0.3 & 0.3 \\
Yield stress $\left(\sigma_{0}\right), \mathrm{MPa}$ & 440 & 565 & 367 \\
Ultimate stress $\left(\sigma_{\mathrm{u}}\right), \mathrm{MPa}$ & 660 & 669 & 659 \\
NDT, ${ }^{\circ} \mathrm{C}$ & -34 & -50 & \\
\hline
\end{tabular}


The full-thickness clad beam tests were instrumented with crack-mouth-opening displacement (CMOD) and load-line displacement (LLD) gages and tested in three-point bending. Each specimen was cooled to the test temperature $\left[-25^{\circ} \mathrm{C}\left(\mathrm{T}-\mathrm{NDT}=25^{\circ} \mathrm{C}\right)\right]$ and then loaded to fracture in displacement control. Details of the test procedures are described by Keeney et al. (1994) and Keeney et al. (1996). The load (P) vs displacement curves for each of the five beams are shown in Fig. 3(a) for LLD and in Fig. 3(b) for CMOD, respectively. These curves depict the inelastic behavior in the shallow-crack specimens as fracture conditions are approached as compared to the near elastic conditions for the deep-crack specimen.

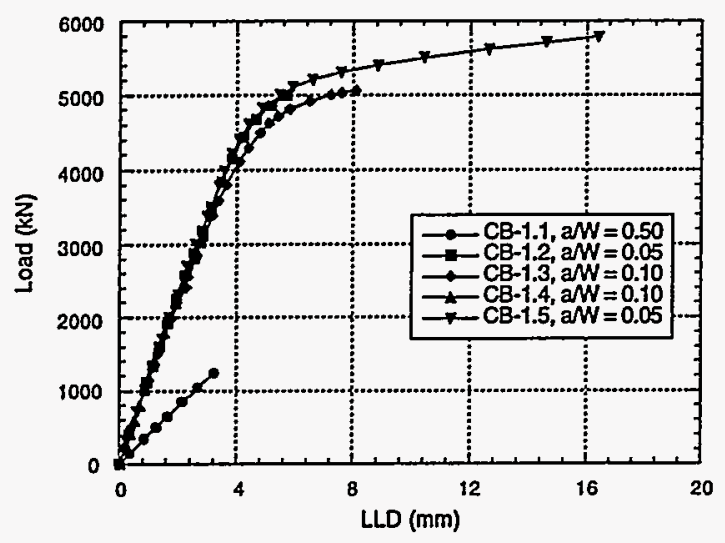

(a)

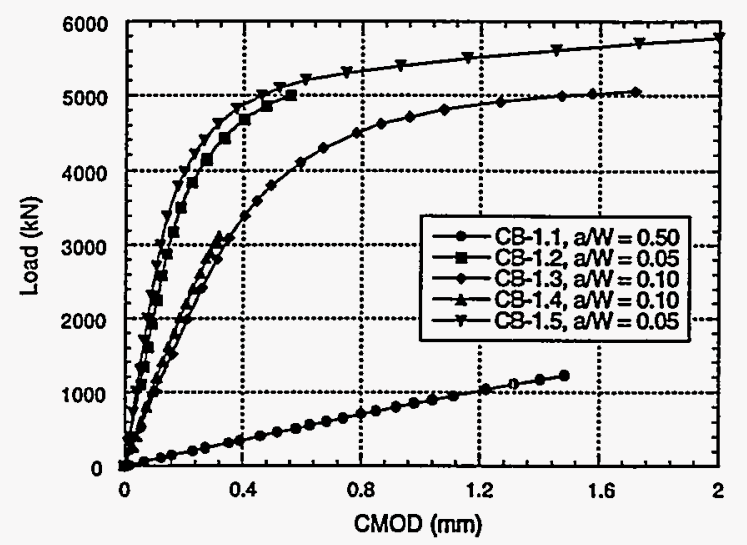

(b)

Fig. 3 Load vs displacement response for clad beam specimens: (a) LLD and (b) CMOD.

\section{FINITE-ELEMENT ANALYSES}

In the HSST Program, initial studies of ductile tearing models have focused on the G-T model for void growth and an element extinction capability for modeling crack growth. Two principal input parameters for the G-T model are the initial void volume fraction, $f_{0}$, and the characteristic length, $D$, associated with the G-T crack plane elements. According to theory, these parameters are dependent only on the material and not on specimen geometry. Ductile crack growth data from side-grooved 1T-CT specimens taken from the weld material have been used to evaluate this model. The parameters $f_{0}$ and $D$ were calibrated for the material through an iterative process involving finite-element analyses of these CT specimens. The calibrated parameters should provide analytical results in agreement with load versus LLD and crack growth data from the CT specimens. Values of these parameters from the CT specimen analyses are then transferred to a large-scale structure (the full-thickness clad beam) to determine if they predict the observed response.

\section{CT Specimen Analysis}

A three-dimensional (3-D) elastic-plastic analysis was performed on the 1T-CT specimen using the finite-element computer code WARP3D (Koppenhoefer et al., 1994). The G-T model implemented in WARP3D incorporates void nucleation and growth ahead of a stably tearing crack into a finite-element model using computational cells with explicit length scales. One quarter of the CT specimen (20\% side grooved and $a / W=0.63$ ) is represented in the finite-element model of Fig. 4(a). The model has 9350 nodes and 7885 elements (8-node bricks), with square elements in the crack-tip region [Fig. 4(b)] and along the crack plane to permit uniform increments of crack extension. The crack-tip element size is $\sim 100 \mu \mathrm{m}$ [chosen from prior analytical experience by Ruggieri and Dodds (1995)] for adequate resolution of the crack opening profile and stresses ahead of the growing crack. The material properties used for all the analyses were taken from Table 3. 


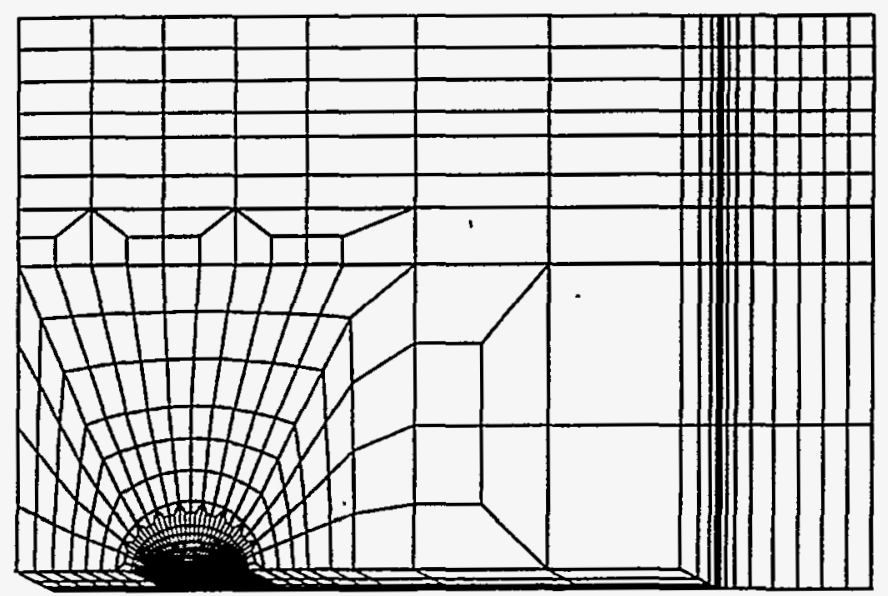

(a)

(b)

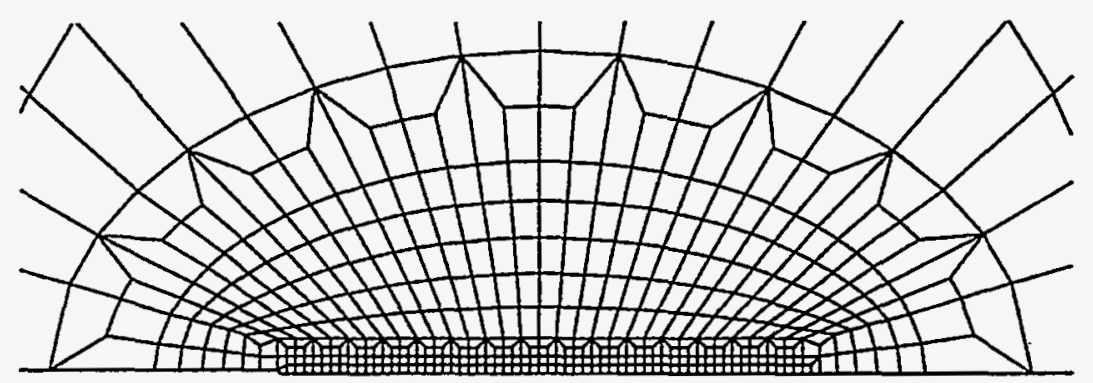

Fig. 4 Three-dimensional finite-element model of 1T-CT specimen: (a) complete mesh, and (b) crack-plane region.

The finite-element model is loaded by displacement increments imposed on nodes at the location of the top of the load-pin hole (not modeled). The Gurson constitutive model is used for the elements along the crack plane where ductile tearing occurs, and the rest of the model uses the von Mises constitutive relation. Calibration analyses were carried out for the explicit length scale $(D)$ of $200 \mu \mathrm{m}$ (since the crack-tip element size is $100 \mu \mathrm{m}$ ) and critical volume fraction $\left(f_{c}\right)$ of 0.3 . The critical volume fraction is when void coalescence occurs and the crack advances. The value of 0.003 for $f o$ gave the best approximation to the measured J vs $\Delta$ a curves. The calculated values for $\mathrm{J}$ and crack extension, shown in Fig. 5, are close to the measured values in one of the CT tests.

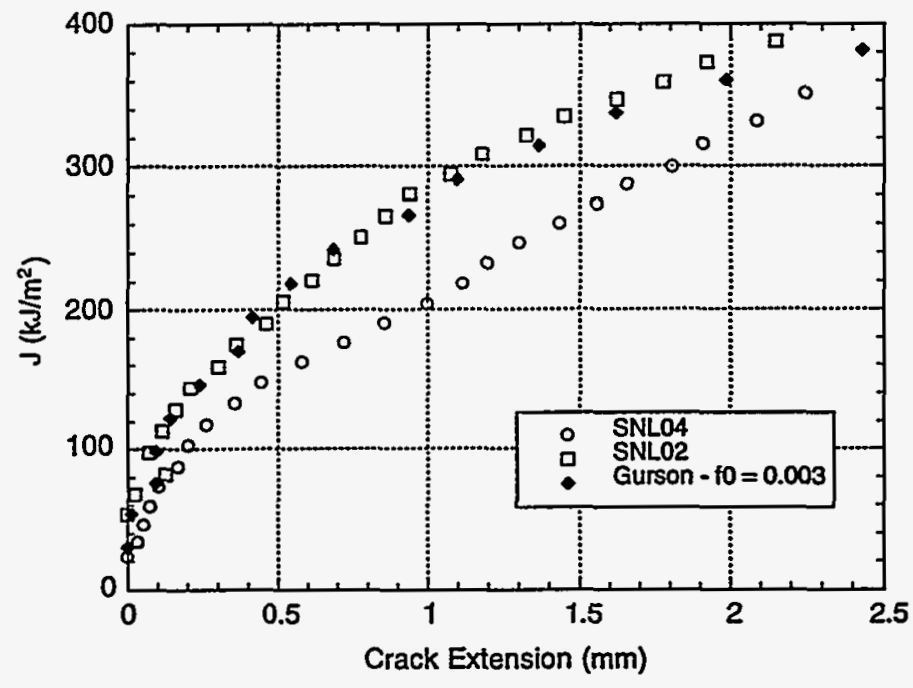

Fig. 5 Comparison of calculated and measured crack extension for specimens fabricated from weld material. 


\section{Full-Thickness Clad Beam Analysis}

The finite-element model shown in Fig. 6 was employed to perform plane-strain, nonlinear analyses of the clad beam specimen $\mathrm{CB}-1.5(\mathrm{a} / \mathrm{W}=0.05)$ which had a small amount of precleavage ductile tearing $(-2.6 \mathrm{~mm})$. The finite-element computer code WARP3D was used to perform the analysis. For 2-D plane-strain analyses, the WARP3D code utilizes a 3-D model with one layer of elements in the thickness direction with plane-strain constraints imposed in the thickness direction on all nodes. In Fig. 6, the model has 2706 nodes and 1248 elements (8-node bricks). Symmetry about the crack plane permits modeling of one half of the specimen. The crack-tip element size is $100 \mu \mathrm{m}$ (same as the 1T-CT specimen model).

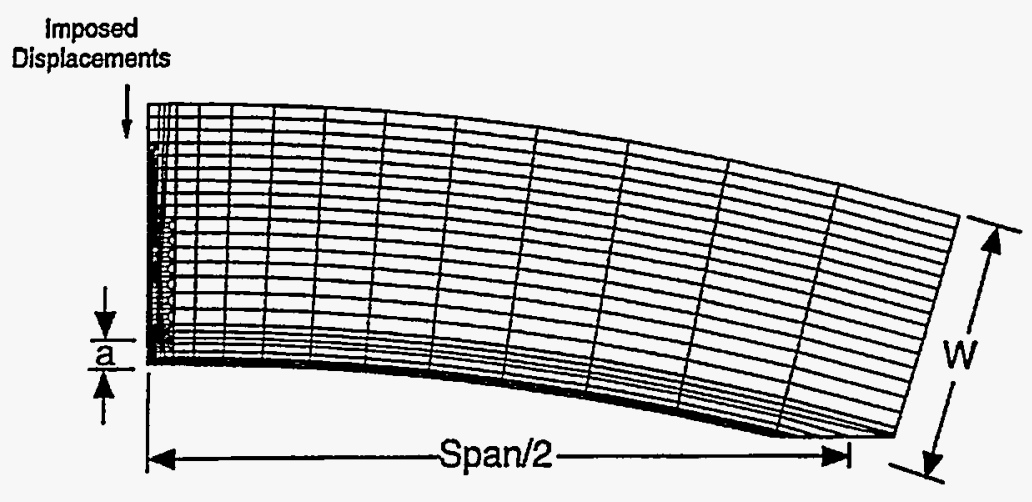

(a)

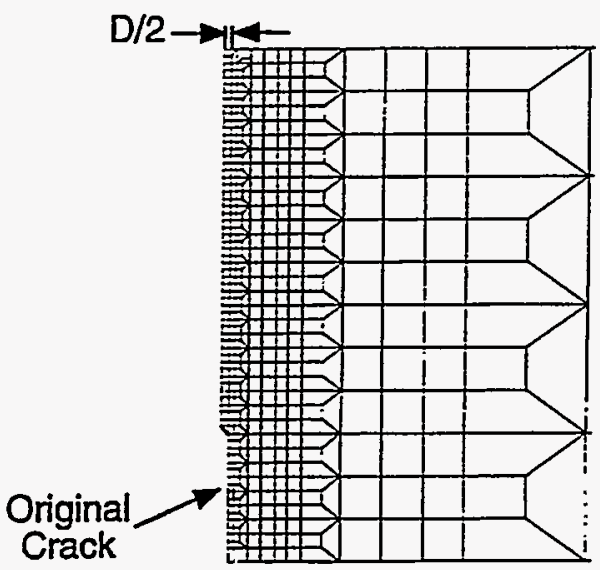

(b)

Fig. 6 (a) Finite-element mesh of clad beam specimen CB-1.5 (a/W = 0.05), and (b) crack-plane region

The finite-element model is loaded by displacement increments imposed on six centerplane nodes (the two end elements) as shown in Fig. 6(a). The input parameters for the G-T model are the same as was used for the CT specimen since theoretically these parameters are dependent only on the material and not on specimen geometry.

Results from the posttest analysis of the clad beam test (CB-1.5) are summarized in Fig. 7(a) and (b) (tests CB-1.1 - CB-1.4 are also included). Comparison of the measured and calculated P vs displacement responses provides a way to interpret the accuracy of the analysis results and to establish confidence in the calculated fracture mechanics parameters. The calculated P vs LLD curves are compared with measured data for each test in Fig. 7(a). For the shallow-crack specimens (CB-1.2-CB-1.4), calculated LLD values at a given load were greater than measured values for the full range of loading. For specimen CB-1.5, the measured values of LLD were greater than the calculated values at a given load over the plastic range of loading. Comparisons 


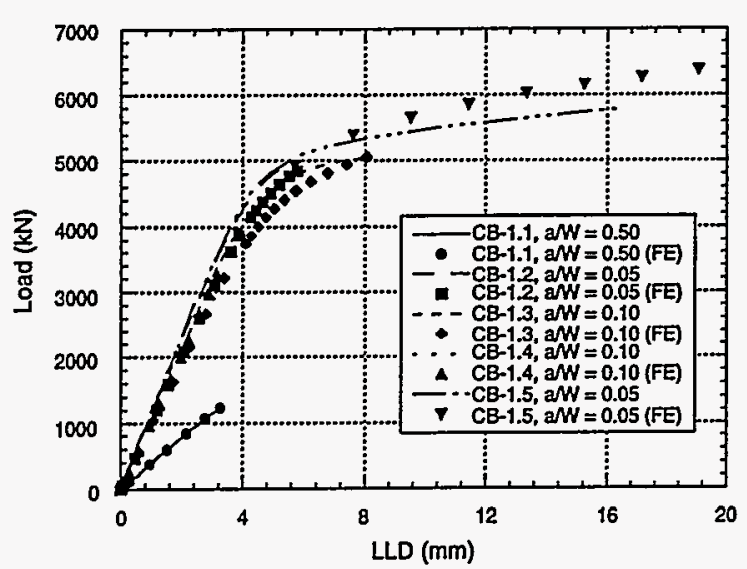

(a)

Fig 7 Calculated and measured displacements for beam

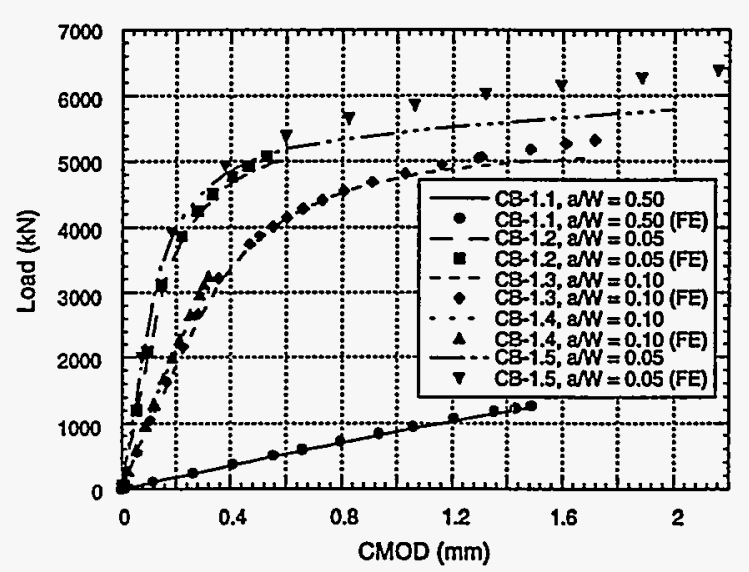

(b)

of calculated and measured P vs CMOD in Fig. 7(b) show good agreement for CB-1.1 - CB-1.4. To match the measured CMOD for CB-1.5, the load had to be increased by $9 \%$. A higher load had to be used because the 3-D plane-strain model is too stiff for an exact comparison between measured and calculated $P$ vs CMOD. Analysis results of CB-1.5, shown in Fig. 8, indicate that the crack began tearing at a load of $4200 \mathrm{kN}$ (J value of $85 \mathrm{kN} / \mathrm{m}$ ). The crack extended to 2.6 $\mathrm{mm}$ at a load of $6060 \mathrm{kN}$ (J value of $720 \mathrm{kN} / \mathrm{m}$ ), which is $5 \%$ higher than the measured cleavage fracture load in the experiment $(5780 \mathrm{kN})$.

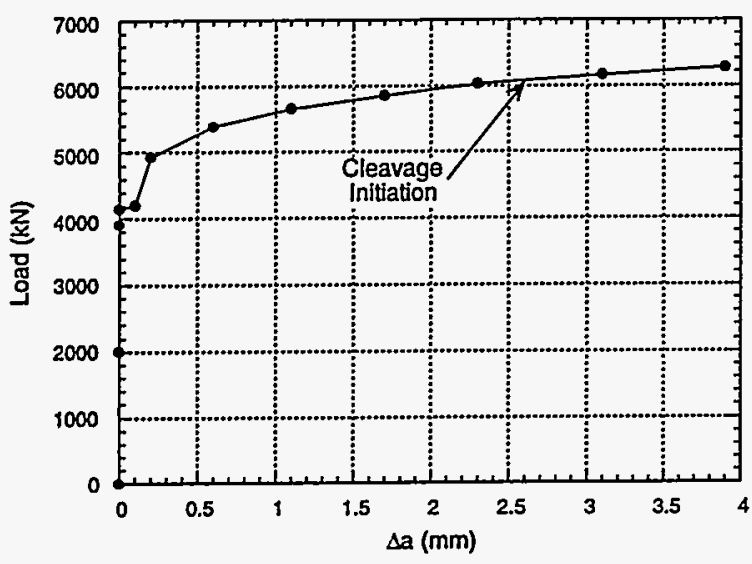

(a)

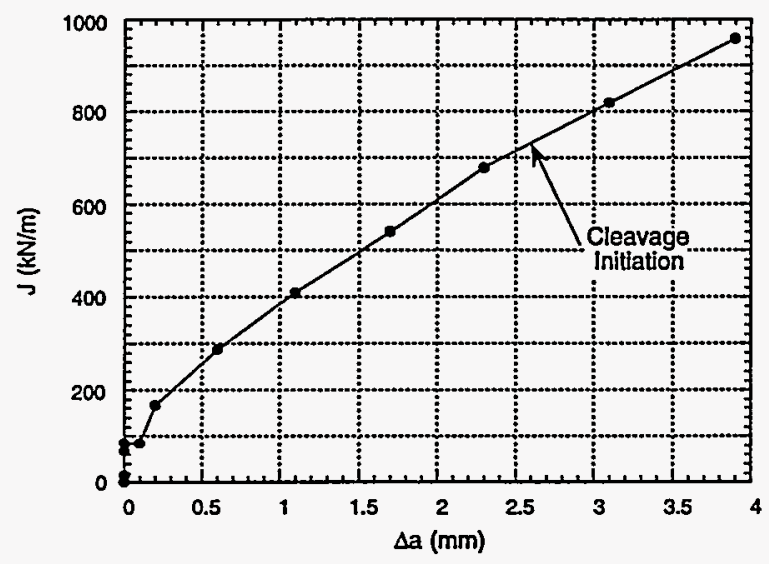

(b)

Fig. 8 Analysis results for clad beam specimen CB-1.5: (a) $\mathrm{L}$ vs $\Delta$ a, and (b) J vs $\Delta$ a.

\section{SUMMARY AND CONCLUSIONS}

Beam specimens, which incorporate RPV fabrication welds, base plate, and weld-overlay cladding, are providing fracture toughness data for shallow cracks in material for which metallurgical conditions are prototypic of those found in RPVs. In the first testing phase, five full-thickness clad beam specimens were fabricated with through-thickness cracks in weld metal that ranged in depth from 10 to $114 \mathrm{~mm}(0.05 \leq \mathrm{a} / \mathrm{W} \leq 0.5)$. These specimens were tested in three-point bending at temperatures in the transition region of the weld metal fracture toughness curve $\left(\mathrm{T}-\mathrm{NDT} \approx 25^{\circ} \mathrm{C}\right.$ ). In tests $\mathrm{CB}-1.1-\mathrm{CB}-1.4$, the cracks initiated in cleavage thus allowing the use of static analysis techniques. The CB-1.5 specimen experienced $\sim 2.6 \mathrm{~mm}$ of stable ductile tearing prior to initiation of cleavage fracture.

Fracture toughness estimates were obtained for CB-1.5 by using finite-element techniques based on the G-T model for void growth and an element extinction capability for modeling crack growth. The two principal input parameters for the G-T model, $f_{0}$ and $D$ were calibrated for the 
weld material through an iterative process involving analyses of the CT specimens. The calibrated parameters provided analytical results in agreement with the crack growth data from the CT specimens. The same values for these parameters from the CT specimen analysis were used in the full-thickness clad beam analysis. To match the measured CMOD for CB-1.5, the load had to be increased by $9 \%$. A higher load had to be used because the 3-D plane-strain model is too stiff for an exact comparison between measured and calculated P vs CMOD. Future work will include the generation and analysis of a full 3-D model of the clad beam specimen, which should result in better agreement between the measured and calculated displacements.

Additional full-thickness clad beams have been tested and results are being evaluated to complete the investigation of fracture toughness of shallow cracks located in prototypical plate material. All of these beams experienced precleavage tearing, so techniques to estimate the toughness in these specimens need to be validated.

\section{ACKNOWLEDGMENTS}

Research sponsored by the Office of Nuclear Regulatory Research, U.S. Nuclear Regulatory Commission under Interagency Agreement 1886-8011-9B with the U.S. Department of Energy under Contract DE-AC05-96OR22464 with Lockheed Martin Energy Research Corp.

The submitted manuscript has been authored by a contractor of the U.S. Government No. DEAC05-96OR22464. Accordingly, the U.S. Government retains a non-exclusive, royalty-free license to publish or reproduce the published form of this contribution, or allow others to do so, for U.S. Government purposes.

\section{REFERENCES}

Cheverton, R. D. and D. G. Ball (1985). Pressurized-Thermal-Shock Evaluation of the Calvert Cliffs Nuclear Power Plant. Martin Marietta Energy Systems, Inc., Oak Ridge Natl. Lab., NUREG/CR-4022, (ORNL/TM-9408), 201-244.

Gurson, A. L. (1977). Continuum Theory of Ductile Rupture by Void Nucleation and Growth: Part I - Yield Criteria and Flow Rules for Porous Ductile Media. Journal of Engineering Materials and Technology, 99, 2-15.

Keeney, J. A., et al. (1994). Preliminary Assessment of the Fracture Behavior of Weld Material in Full-Thickness Clad Beams. Martin Marietta Energy Systems, Inc., Oak Ridge Natl. Lab., NUREG/CR-6228, (ORNL/TM-13091).

Keeney, J. A., B. R. Bass and W. J. McAfee (1996). Fracture Analysis of Full-Thickness Clad Beam Specimens. In: Fracture Mechanics: 27th Volume, ASTM STP 1296 (Robert S. Piascik, James C. Newman, Jr., and Richard P. Gangloff, Eds.), American Society for Testing and Materials, Philadelphia.

Koppenhoefer, K. C., A. S. Gullerud, C. Ruggieri, R. H. Dodds, Jr., and B. E. Healy (1994). WARP3D: Dynamic Nonlinear Analysis of Solids Using a Preconditioned Conjugate Gradient Software Architecture. Department of Civil Engineering, University of Mlinois, UILU-ENG-94-2017.

Marshall, W., et al. (1982). An Assessment of the Integrity of PWR Pressure Vessels. UKAEA Study Group Reports.

Ruggieri, C. and R. H. Dodds, Jr. (1995). Constraint and Ductile Tearing Effects in Statistical Analyses of Cleavage Fracture. Department of Civil Engineering, University of Illinois, UILU-ENG-95-2011.

U. S. Nuclear Regulatory Commission Regulatory Guide 1.154 (1987). Format and Content of Plant-Specific Pressurized Thermal Shock Safety Analysis Reports for Pressurized Water Reactors. 